\title{
How Did the Yakuts Fortify Themselves against the Cold?
}

\author{
Svetlana Ivanovna Petrova \\ M.K. Ammosov North-Eastern Federal University, Yakutsk, Russia \\ Email: sakhafolklor@rambler.ru
}

Received 20 January 2015; accepted 9 March 2015; published 13 March 2015

Copyright (C) 2015 by author and Scientific Research Publishing Inc.

This work is licensed under the Creative Commons Attribution International License (CC BY). http://creativecommons.org/licenses/by/4.0/

c) (i) Open Access

\begin{abstract}
This article is dedicated to the analysis of the heat-insulating function of winter clothes and personal cold-protective equipments (protectors), which grew out of use at the beginning of the XX century and now are kept in different museum funds. The author pays the main attention to the description of the material, production technologies, and functional heat-insulating properties of the traditional winter clothes and protectors. The article also discusses ethnocultural parallels of the traditional clothes.
\end{abstract}

\section{Keywords}

Clothes, Fur, Skin, Cold Protection, Originality, Unicity, A Headband, A Nasel, A Wrist Warmth Keeper, A Waistcloth, A Plastron, A Drawer

In the Yakut ethnography of recent years, an increased scientific interest to the clothes complex analysis in the general system of material and spiritual culture of the Yakuts was seen. There are thoroughgoing historicalethnographical and culturological researches directed to the analysis of the structural-semantical and artisticconstructional peculiarities of the Yakut traditional clothes. To begin with, it is important to note a fine art expert Gavrilieva R.S.’ work [1] related to historical-ethnographical research of the traditional Yakut clothes. In the chapter I, she discussed the everyday and ceremonial functions of drawers, gaiters, and waistcloths. Rastorgueva L.N. [2] covered in her researches a very important problem of modern development and methods of clothes designing on the basis of traditional production technologies of the Yakut clothes. But her analysis of the traditional personal cold-protective equipments was rather fragmentary where much attention was directed to the modern technological methods of protectors’ production. This author covered the semantic structure and symbolic complex of ceremonial Yakut clothes, but the heat-insulating function of them was not investigated because the stress was made to the ritual-ceremonial functions of the clothes [3]. Some elements of the ancient protectors as a fur necklet, a plastron, etc. were discussed in the work of Tyrylgin M.A. [4]. The art aspects of 
the Yakut national clothes were covered in the works of fine art experts Ivanova-Unarova Z.I. [5] and Zabolotskaya Z.M. [6], where they analyzed some kinds of overclothes and special thermal insulations from the American Museum of Natural History in terms of art science. But in spite of it, there are some problems at the present times in the reconstruction of the Yakut clothes, traditional personal cold-protective equipments and their adaptation in the modern sociocultural space.

The objective of the article is the analysis of the heat-insulating functions of the traditional winter clothes and the reconstruction of personal cold-protective equipments adapted from the Republic and Russian museums' materials and author's field data.

The ethnographic materials of the Miklukho-Maklai Institute of Ethnology and Anthropology of the Russian Museum of Ethnography in St. Petersburg have been used in the article. The Republic's and uluses' historical local lore museums fund collections of the Republic of Sakha (Yakutia) provided our research with interesting materials. There are some types of protectors in these museums preserved in single exemplars.

Yakutia with its natural and climatic conditions is the severest territorial-climatic zone for living. But nevertheless, people inhabiting this vast territory, including the Yakuts, during a centuries-long period of their living here have favorably been having all kinds of hunting and ranching. Their necessary adaptation to low temperatures, severe cold and frost, reaching 50 - 60 degrees below zero, made them wear clothes consisting of many parts usually from fur and skins of domestic and wild animals. In such immensely harsh climatic conditions, the Yakuts were very selective concerning the utility and adaptiveness of their traditional clothes to low temperatures; they had to contrive different personal cold-protective equipments and protectors.

Modern researches of artistic and compositional clothes arrangement studies shows that the peculiarities of northern conditions adapt clothes are the technology of fabrication (doubling, i.e. covering fur with fur), a functional way of arranging (large volume of clothes, wrapover clothes with a closing), and ornamental finishing (a broad 2- or 3-rows fur binding of a lower hemline, sleeves, a back vent of the back and a forearm) ([3], p. 5-21; [6], p. 6-10).

The Yakuts wore worked skins of domestic and wild animals over overclothes, used them as ornamental furnishings and as thermal insulations under outer garments. Ancient handy women tried to make rough skin of any animal extra tender and elastic in such a way giving them pleasant qualities such as cleanness of fluff, smoothness and beautiful coloring. The first contradictory descriptions of traditional materials manufacturing for leather and hide clothes appeared in the works of Neiman K.K. and Seroshevsky V.L. According to Neiman, leather, which was curried "in a Yakut way", had rather law quality ([7], p. 59); Seroshevsky in his turn said that the Yakuts curried beautiful, supple leather of high quality, resistant to wetness ([8], p. 358). In accordance with materials of the museums funds, the Yakuts, as well as other northern peoples, reached amazing achievements in this sphere, which are now incontestable proofs of their age-old distinctive character of manufacturing technology.

In the documents of the XVIII and XIX centuries we can find only fur archaic kinds of clothes. On going far away, men and women put on fur-coats with fur outward—sangyiakhs (arbagas, kennuges, khotoidokh son) over short fur and leather overcoats (son) ${ }^{1}$. These fur-coats often were unlined but sometimes their inner lining was woolen ([8], p. 322, 232). Traveling fur-coats was long to protect a body against cold at full length. They were sewn of tarbagan, fox skins or skin of deer, beaver, lynx; a lining was made of the combination of squirrel and ermine skins because they were more wearproof. A lining of one fur-coat was made usually of 250 - 300 squirrel or ermine skins. In the past there were also woolen coats with a fur lining and a behind vent with fur border on the all periphery of the coat, which prevented cold air get inside the cloth. The underside of the coat was very broad due to freely dangling insets-kokuora ono. These insets had not ornamental but practical purposes: while riding or sitting in a sled such broaderings tightly wrapped up the front part of a body and in such a way prevented legs and a groin against cold. As described in the materials of the All-Russian Hygienic Exhibition, "The sleeves on the shoulders have puffs with free space in them for accumulation of air warmed by shoulder-joints to protect these joints against chill...” ([4], p. 174). The puffs of many coats from museum funds have a function of protection a humeral against cold. A forepart of the coat fastens with a two-sided deep wrap-up in such a way to protect a breast against high wind. Some fur collars were broad to protect an occipital lobe; sleeves were long and sometimes fur-edged.

\footnotetext{
${ }^{1}$ The Local Lore Museum in Srednekolymsk, a fur coat— khotoidokh son, inv. №95, Srednekolymsk, the Republic of Sakha (Yakutia).
} 
A smart coat (buktakh son) was a cloth of the same type; it was a property of the rich and notable people because besides expensive furs there were also usually silver, golden sewing, expensive silk and woolen fabrics on the coat inaccessible to the poor. Rich in ornament and decorated coats are exhibited at the expositions of the Russian Museum of Ethnography. The peculiarities of the costume were sticking up alar insets sidelong $37 \mathrm{sm}$ beneath a shoulder (kokuora ono) ${ }^{2}$ which had not ornamental but practical purposes for broadening of the clothes underpart and at the same time for protecting the lower body against frost during long riding ([3], p. 56). The remarkable fact is that this Yakut cloth (buktakh son) is similar both to a Khakas wedding fur-coat idektig ton with a fur lining and a welt, and to women's overclothes of some ethnicities of Tibet's peoples ${ }^{3}$. We observed that they are identical in the material usage, a cut, and the arrangement of finishing. The Yakut coat "buktakh son" was sewn around by silk fabrics and fur on the edges, had a broad turndown collar. As Butanaev V.Y. described, the Khakas coat collar was also turndown, it was made of fur of otter or beaver, and was sewn around by an expensive silk border ([9], p. 566).

Men's overclothes sometimes were bordered by sable fur along welts, had a hem, and a back vent 4 sm width, they were tied with three-four pairs of straps from deerskin. Sometimes these clothes also had fur lining ([10], p. 47-48).

A differential characteristic of the Yakut clothes is their complex structure consisting of many parts. Men and women wore double headdresses: lower fur bonnets clung people's heads; upper fur headdresses had large volume. Upper headwears were made usually of several types of fur-lynx, wolf, fox, glutton, and sable-with hidden scalps these headwears also had a furring from small deer-hare, squirrel, ermine or fox paws-to increase a heat-protecting function. Detailed descriptions of headdresses can be found in archive materials. For example, the notes of the ethnographer Bolo S.I. say that the edge of the headwear nuogaidakh bergese (a headwear with a feather tassel on its top) can be made of a black hog colt skin with a sort of furry moss. Its cervical part was sewn of a thin skin of a black suckling colt without underfur; a welt of the occipital lobe was sewn of a skin of a cream hog colt with fluffy hair ${ }^{4}$. Summer variants of headdresses were sewn of different pieces of fur, leather, and fabric; they also were worn in winter under upper headwears. The poor wore headwears made of duck scalps (kus bataga bergese), calf pubises (torbos bataga bergese), and worked animal bladders (khabakh bergese); the constructions of such headwears were rather unordinary.

A headdress djabaka had a very interesting construction consisting of several parts. A front fur part was called kharata (a black side), which reliably protected a frontal part of a head; a back fur part-urune (a white side). Bordered fur of the headwear was called buodjuta - a border; a fur lower part of a back side was called khadjasyna, which encased an occipital lobe of a head and shoulders with the help of its longness ([11], p. 228). In the XIX century men smart headdress was a headwear made of fox "ski climbers"-kurasky. In its shape it resembled a headwear of the South Altaians (altai berik) with a spool-shaped form. This headwear was furred inside, and covered with fox "ski climbers" outside (tys) in such a way to converge black edges on the top. The lower edge of it was bordered with fur of fur seal or kalan.

In severe winter conditions the Yakuts protected themselves with original and comfortable facilities-personal cold-protective equipments such as a fur collar, a plastron, a headband, a nasel, a fingerstalls, a wrist warmth keeper, mitts without fingerstalls, a waistcloth, an abdominal belt, etc. In their construction they were rather simple of a rectangular or spool-shaped forms; their inner lining was always furred and born against a body not to let cold air get inside. Thermal insulations for underclothing wearing usually were made of simple hare fur, but the insulations with aesthetic function, especially women's ones, were made of sable or fox fur and were decorated with beads, embroidery, and metal plates. For example, such insulations as a headband (sjuus sabyta) and a thermal insulation for a chin (seniye samnaga) keeping in the funds of the Russian Museum of Ethnography ${ }^{5}$ are graphically beaded with adding of metal plates. Some informants said that in the ancient times people wore fur wrist and fist warmth keepers, and nasels $s^{6}$. Types of breathing organs thermal insulations are a long fur collar (a necklet)—moitoruk and a plastron—tusuluk. "They hide their chins, mouths, cheeks, and noses

\footnotetext{
${ }^{2}$ The Russian Museum of Ethnography (hereafter RME), inv.№ 478-2, St. Petersburg, Russia.

${ }^{3}$ Field data of the author. The culturological expedition to Nepal, 2003.

${ }^{4}$ Archive of the Yakut Scientific Center of the SB RAS. Bolo S.I. Ethnographical materials 1938 F.5.OP.3.D.27.L.8.

${ }^{5}$ Wristbands-inv. № 437-1/1-2; a plastron-inv. № 437-2; a headband—inv. № 437-3.

${ }^{6}$ Field material of the author, 1996. The Historical Local Lore Museum in Zhigansk. Scientific certification of the exhibits wasn’t held. The information of Shadrina A.P.
} 
in the collars while traveling. They breathe through fur of the collar to moderate a bit swallowed air in hard cold. When breath damps the collar making it unpleasant for touching, they turn it overside; at this time a wet side quickly gets dry in icy air and easily gets clear while being shaking off” ([12], p. 262). A collar was very comfortable and universal; it protected breast, a throat, and nape against cold perfectly. A traditional Yakut necklet moitoruk was sewn of 100 - 150 worked fox nails by stringing them on a thread. Necklets can be of different length depending on the amount of stringed nails and reaching at times $1.5-2 \mathrm{~m}$ length. A necklet from the Historical Local Lore Museum in the village Maiya has 115-sm length, 11-sm cross-section diameter ${ }^{7}$. Necklets from hare skin or fox nails can rarely be found in the museums funds.

There were necklets with original element used for shacking ice off the collar. The only exemplar of such fur necklet is preserved in the Museum of Ethnopedagogics in Verkhne-Viluisky ulus of the Republic of Sakha (Yakutia). This element consists of seven bright multicolored flaps from silk fabrics; it has a prolonged pentagonal form and tassels in the lower part ${ }^{8}$.

A fur plastron (tusuluk) had a trapezoidal form and could be short or long. Long plastrons were tied on the back part of a neck and from below a loin in such a way to protect breast against cold. Plastrons for women were usually embroidered with colored stitching or beaded. There is a material about a plastron for men decorated with metal plates in the book of Seroshevsky V.L. ([8], pict. 100, p. 376).

Interesting additional elements of overclothes are belt types of clothes: an abdominal belt (bachy) and a waistcloth (belepchi). The abdominal belt is a broad fur belt with fur inward perfectly protecting a lower part of a belly against chill. Troschansky V.F. noted that the Yakuts had been wearing abdominal belts during all winter ([13], p. 120). As Ivanova-Unarova Z.I. described, there are interesting abdominal belts exemplars in the American Museum of Natural History. The author noted that the first belt had been sewn from hare skin and the second one- from fox skin and decorated with metal plates from outside ([5], p. 58).

Early data concerning waistcloths can be found in a work of Sarychev G.A. He marked that "prosperous Yakuts wore waistcloths tied to a belt over dresses; these waistcloths consisted of two four-sided flaps of red and blue clothe wool" ([14], p. 42-43). Waistcloths could be fur bordered. The materials of "Popular decorative applied art of Kirghizia" album say that the Yakuts and the Buryats apparently inherited this type of clothe from the Qurykans - their Turco-speaking ancestors in the Baikal Lakeside, and the Kirghiz-from the Yenisei Kyrgyz. The name had probably derived from an Old Turkic word "bel” meaning "a loin” ([15], p. 268). The Yakut waistcloth belepchi was usually used for protecting coat's fur against chafing while riding and people against cold.

Warm drawers for winter (syaldja) were sewn with fur inward; summer drawers sary syaldja were sewn from smooth deerskin ${ }^{9}$. Some informants said that for distant traveling people put on thermal insulations with fur outward under drawers (habah hata - "a pouch for a bladder"-a word for word translation) to protect groin. Its construction was very interesting: it had a pants form but unclosed from two sides, and was tied from one side with four leather strings. A back part is the most interesting with its special slash vent ${ }^{10}$. Such original kind of warm clothes was surely comfortable for wearing during distant trips and convenient for protection female organs and kidneys against various diseases.

In former times the Yakuts had many types of everyday, traveling, and hunting mitts. Mitts for hunting were sewn from paws of fox, wolf, and dog skin.

All mitts were furred from outside and inside. The inner side lining was made of hare, polar fox, and squirrel skin. Traveling mitts were popular among Northern Yakut reindeer breeders; such mitts sewn from bear or deer skin with fur outward reached elbows and covered small mitts made of hare skin ([16], p. 90). Mitts for children $k u p c h u^{11}$ were sewn with fur inward and with long deerskin strings but without fingerstalls.

Almost all types of mitts had a crosscut near wrist from a palm side and a hand (uostakh utuluk_"mitts with a cut"- - a word for word translation); this helped to take hands out for working not taking mitts off while a back side of hands were covered. Maak R.K. gave a more detailed description of mitts' cut purpose: "People had often to put their mitts off while traveling in winter to tie or untie a belt or something of the sort in the traces or to repair set traps for small deer on the hunting field, or to take fish out of flues, creels or hooklets. On all such oc-

${ }^{8}$ Field material of the author. 1996. The Museum of Ethnopedagogics of Verkhne-Viluisky ulus, the Republic of Sakha (Yakutia). Scientific certification of the exhibits wasn't held.

${ }^{9}$ The RME, inv. № 1071-73.

${ }^{10}$ Field material of the author. 2010. The exhibition to Baiaga village in Tattinsky ulus, the Republic of Sakha (Yakutia). Information of a national craftsman Neustroev B.F.

${ }^{11}$ Field material of the author. Zhigansky ulus, the Republic of Sakha (Yakutia). 1995. Information of Shadrina A.P.
} 
casions a cut on mitts was a very practical appliance” ([9], p. 228). Such mitts were also furred.

In winter while working in freezing temperatures fur wraps for hands with strings and without fingerstalls (belepchi) were very comfortable; they were put on under mitts. Pekarsky’s Ditionary has some information about such wraps made of water rat skin ([17], p. 39). During distant trips people put on fur fingerstalls of hare skin on every finger ${ }^{12}$.

A waistcloth and a cover for a back part of a hand (a wrap) have a general name- belepchi ${ }^{13}$.

Fur kurumu and burpekh made of chamois are warm kinds of footwear with high bootlegs for hunting. One exemplar of such footwear is preserved in the Russian Museum of Ethnography ${ }^{14}$. These shoes were used usually by hunters; they were very comfortable for hustling through deep snow in winter and through slashes in spring and autumn: their skin working didn't let them get wet.

Winter shoes also consisted of fur gaiters—suturuo. The gaiters were usually tied to drawers and reached the ankles. Their upper edges deeply covered the armholes of drawers. Depending on a season, they were sewn from deerskin or fur. Such original componential type of clothes was apparently created due to severe climatic conditions. The author succeeded to find interesting gaiters made of diver fur in the Historical Local Lore Museum in Zhigansk. This fur was obviously used because of its waterproof properties. Drawers together with gaiters composed one cloth generally replacing trousers ${ }^{15}$.

Special types of winter footwears are fur knee-protectors, stockings, and very short fur shoes-olochu. These shoes were sewn with fur inward and were worn over main fur shoes in winter during distant trips. On such occasions, olochu were very comfortable; they were put off during stopovers and dried on the fire. Winyter road outfit consisted of stockings sewn from homespun coat wool or worked deer paws (charas kenche). These stockings were covered with fur stockings (istekh kenche). After that, main shoes made of deer "ski climbers" (eterbes) were put on. Kenchi made of calf, coltish, and deerskin skins were inwardly furred. Fabric stockings were sewn around with hare skin inside and sometimes had a thin fabric lining. The cut of kenchi was similar to the cut of leather shoes but with a simpler form and without toes. Konstantinov I.V. found the samples of such stockings in man burial № 27. These were two pairs of stockings made of calfskin with fur inward. The third pair was made of cuttings of fox skins with fur inward ([11], p. 75). Hunters still put on fur kenchi at present. People's feet were also insulated with bedding made of dried hay or fur. Mitts were also insulated in this way. Beddings made of horsehair (ugunia) were rather original ${ }^{16}$. They perfectly conserved heat while wearing and were accessible for everyone. Seroshevsky V.L. in his work wrote interesting notes about the order of putting on of footwear by the Yakuts: "On going to a long trip, first of all a Yakut changes a bedding of dried grass, then he puts on his bare feet on stockings made of hare or calf skin with fur inward, then he puts on small sneakers made of the same skin with fur inward, and afterwards he puts on boots made of sara and torbasa. Knee-caps are always put in shanks; then another road fur knee-caps (suturuo) are drawn in over them with fir outward. These knee-caps are tightened under knees and freely embrace thighs not to let snow, rain or wind reach a lower dress which should always be dry. Upon arrival a Yakut first of all puts suturuo off ” ([8], p. 327).

As can be seen from the above, the ancient Yakut clothes were very practical and comfortable in the conditions of low temperatures. The heat-insulating function of these clothes was defined by the usage of fur materials' and clothes' constructional cut. The original construction and finishing of clothes and unique extra means of personal cold-protection made people's figure volume, but they reliably ensured complex protection against frost and cold. Such materials as fur, skin of domestic and wild animals, and fur games helped in this protection. By the early XX century, these types of clothes felt out of use due to delivery and blanket distribution of European types of clothes. As artifacts of material culture, they became only a subject of consideration and admiration. It's important to note that nowadays hunters still use armlets and fur beddings for shoes. While producing winter clothes and their additional elements, handy women paid much attention not only to their life-supporting functions but also to aesthetic ones. Winter clothes were decorated with colored and golden stitching embroidery, and were beaded in combination with metal plates; they were not only very warm but also beautiful, smart, and comfortable in use.

\footnotetext{
${ }^{12}$ Field material of the author, 1996. The Historical Local Lore Museum in Zhigansk. Scientific certification of the exhibits wasn’t held. Information of Ivanov D.I.

${ }^{13}$ The information about the name belepchi wasn't found in the Dictionary of Pekarsky E.K. (T.1-3, 1958, 1959).

${ }^{14}$ The RME, St. Petersburg. Inv. № 437-30.

${ }^{15}$ Field material of the author, 1996. The Historical Local Lore Museum inZhigansk. Scientific certification of the exhibits wasn’t held. Information Shadrina A.P.

${ }^{16}$ Field material of the author, 2009, Verkhne-Viluisky ulus, the Republic of Sakha (Yakutia). Information of Borisova S.D.
} 


\section{References}

[1] Gavrilieva, R.S. (1998) Odezhda naroda sakha kontsa XVII—seredinï XVIII veka [The Sakha People’s Clothing in the End of the $17^{\text {th }}$ - In the Middle of the $18^{\text {th }}$ Century]. Nauka, Novosibirsk.

[2] Rastorgueva, L.N. (1999) Sredstva individyal'nogoi sashitï cheloveka na Severe [Personal Protection Equipments in the North: Traditions and Modern Developments]. Kuduk, Yakutsk.

[3] Petrova, S.I. (2006) Svadebniii nariad iakutov: Traditsii i rekonstruktsia [The Sakha Wedding Costume: Traditions and Reconstruction]. Nauka, Novosibirsk.

[4] Tyrylgin, M.A. (2000) Istoki fenomehal'nou zhiznesposobnosti naroda sakha [The Beginnings of Phenomenal Viability of the Sakha People]. Bichik, Yakutsk.

[5] Ivanova-Unariva, Z.I. (2001) Yakutskia kolleksia v Amerikanskom muzee estestvennou istorii [The Yakut Collection in the American Museum of Natural History]. Dialog: Museum and Society, Yakutsk.

[6] Zabolotskaya, Z.M. (2005) Khudozhestvenno-kompozisionnoe reshenie traditsionnoi yukutskoi odezhdï [ArtisticCompositional Arrangements of Traditional Yakut Clothes]. IP Zabolotsky, Yakutsk.

[7] Neiman, K.K. (1872) Neskol’ko slov o torgovle i promï shlennosti severnï kh narodov Yukutskou oblasti [Several Words about Trade and Industry of the Northern Peoples of the Yakut District]. Izvestia VSORGO [Proceedings of the East-Siberian], Department of the Russian Geographic Society, Irkutsk.

[8] Seroshevsky, V.L. (1993) Yakutï. Opït ethnograficheskogo issledovania [The Yakuts. The Experience of the Ethnographical Research]. ROSSPEN, Moscow.

[9] Butanaev, V.Y. (1997) Khakasï [The Khakas]. The Turkic Peoples of the Siberian District. Nauka, Moscow.

[10] Konstantinov, I.V. (1971) Odezhda i ukrashenia yakutki [Clothes and Ornamentals of a Yakut Woman]. Yakutknigoizdat, Yakutsk.

[11] Maak, R.K. (1994) Viluisku okryg Yukutskou oblasti [Viluisky District of the Yakut Region]. Yana, Moscow.

[12] Narodï Rossii: Ethnograficheskie ocherki [Nations of Russia: Ethnographical Sketch-Books]. St. Petersburg, 1980.

[13] Troschansky, V.F. (1911) Nabroski o yakutakh Yakutskogo okruga [The Sketches about the Yakuts of the Yakut District]. Kazan.

[14] Sarychev, G.A. (1952) Putechestvie po severo-vostochnu chasti Sibiri [Traveling to the North-Eastern Part of Siberia, the Ice Sea, and the Eastern Ocean]. Gos. Izd. Geogr. Lit, Moscow.

[15] Narodnoe dekorativno-prikladnoe iskusstvo Kirghizii [National Applied and Decorative Arts of Kirghizia]. Moscow, 1968.

[16] Gurvich, I.S. (1977) Cultura severnïkh yakutov-olenevodov [Culture of the Northern Yakut Reindeer-Breeders. Revisited the Late Stages of the Yakut People Formation]. Nauka, Moscow.

[17] Piekarski, E.K. (1958) Slovar’ iakutskogo iazïka: V 3 tomakh [Dictionary of the Sakha Language: In 3 Volumes]. Izdatel'stvo AN SSSR, Moscow and Leningrad. 